\title{
HUBUNGAN NILAI ANKLE BRACHIAL INDEKS DENGAN FUNGSI KOGNITIF PADA LANJUT USIA
}

\author{
Lydia Susanti ${ }^{1}$, Yuliarni Syafrita ${ }^{1}$
}

\begin{abstract}
Abstrak
Peningkatan angka harapan hidup menyebabkan pergeseran pola penyakit dari penyakit infeksi ke penyakit degeneratif seperti hipertensi, diabetes melitus, serta aterosklerosis. Aterosklerosis pada tahap awal yang dikenal dengan atherosclerosis asimptomatis sering ditandai dengan adanya Peripheral Arterial Disease (PAD). Ankle Brachial Index (ABI) adalah ratio tekanan sistolik ankle dan brachial yang dapat digunakan untuk menilai severitas oklusi arteri perifer yang merupakan gambaran penyumbatan arteri secara umum. Tujuan penelitian adalah untuk mengetahui hubungan antara nilai $A B I$ dengan fungsi kognitif. Penelitian dilakukan pada 75 pasien lanjut usia yang berobat ke poliklinik saraf RS DR M Djamil Padang dengan metode consecutive sampling. Pemeriksaan fungsi kognitif menggunakan Indonesia Montreal Cognitive Assessment (InaMoCA). Data dianalisa dengan uji $\chi 2$ dengan nilai $p<0,05$. Hasil penelitian didapatkan gangguan sebanyak 48 orang (64\%). Nilai $A B I$ yang rendah sejumlah 31 orang $(41,3 \%)$, normal 44 orang $(58,7 \%)$. Tidak didapatkan hubungan langsung antara nilai $A B I$ dengan fungsi kognitif $(p>0,05)$. Namun setelah sampel dispesifikasikan berdasarkan jenis kelamin, hubungan antara $A B I$ dengan fungsi kognitif pada wanita bermakna secara statistik $(p<0,05)$. Kesimpulannya, tidak terdapat hubungan antara nilai $A B I$ dengan fungsi kognitif pada lanjut usia, namun terdapat hubungan antara nilai $A B I$ dengan fungsi kognitif pada lanjut usia berjenis kelamin wanita.
\end{abstract}

Kata Kunci: Peripheral Arterial Disease, Indonesia Montreal Cognitive Assessment (InaMoCA), fungsi kognitif, lanjut usia.

\begin{abstract}
Increased life expectancy has led to a shift in disease patterns from infectious diseases to degenerative diseases such as hypertension, diabetes mellitus, and atherosclerosis. Atherosclerosis at an early stage, known as asymptomatic atherosclerosis is often characterized by the presence of Peripheral Arterial Disease (PAD). Ankle brachial index ( $A B I)$ is the ratio of ankle and brachial systolic pressure which can be used to assess the severity of peripheral arterial occlusion that represent a blockage of arteries in general view. The aim of this study is to assess association between $A B I$ and the Indonesia Montreal Cognitive Assessment (InaMoCA). This is a cross sectional study. The study was conducted on 75 elderly people at the Neurology Outpatient of DR. M. Djamil Hospital Padang, taken by consecutive sampling technique. Cognitive assesment si done using the InaMoCA examination. Result is analyzed with $\chi 2$ test with $\mathrm{p}<0.05$. The result showed disorder obtain in 48 sample (64\%). Low $A B I$ value in 31 sample (41,3\%), normal in 44 sample $(58,7 \%)$. There was no association between $A B I$ with MoCA $(p>0.05)$. But, based on gender classification, there was association between $A B I$ value in women $(p<0,05)$. The conclusion is no association between $A B I$ with InaMoCA in elderly, but we found association between $A B I$ and InaMoCA in women.
\end{abstract}

Key words: Peripheral Arterial Disease (PAD), Indonesian Montreal Cognitive Assessment (InaMoCA), cognitive function, elderly.

Afiliasi Penulis: 1. Bagian IImu Penyakit Saraf Fakultas Kedokteran Unand/ RS DR M Djamil Padang Indonesia. Jl. Perintis Kemerdekaan No. 94 Padang 25127. Korespondensi: Lydia Susanti, email: lydiasusanti99@gmail.com. 


\section{PENDAHULUAN}

Pembangunan

kesehatan yang komprehensif dan berkesinambungan berdampak terhadap meningkatnya derajat kesehatan masyarakat secara menyeluruh dan meningkatnya angka harapan hidup. Peningkatan harapan hidup menyebabkan meningkatnya jumlah populasi lanjut usia. Perubahan ini diikuti dengan bergesernya pola penyakit dari penyakit infeksi ke penyakit degeneratif seperti hipertensi, diabetes mellitus, serta aterosklerosis. ${ }^{1}$

Peripheral arterial disease (PAD) adalah manifestasi paling sering dari aterosklerosis. Keadaan ini pada tahap awal sering tanpa gejala sehingga kejadian kasus ini secara pasti sulit untuk ditentukan.

Prevalensi PAD meningkat dengan bertambahnya usia dimana lebih dari $20 \%$ adalah usia diatas 70 tahun. $^{2}$ Menurut Newman dan kawan kawan, faktor risiko terbesar dari PAD adalah merokok (6,2\%), Diabetes mellitus (3,5\%) dan hipertensi $(2,0) \cdot .^{3,4,5}$

Pembagian gejala klinis PAD yang paling sering digunakan adalah berdasarkan Fontaine Classification $^{6}$ : tahap I asimptomatik, tahap II claudicatio intermitten, tahap III nyeri pada waktu istirahat atau pada malam hari, dan tahap IV nekrosis atau gangrene.

Kejadian PAD tidak hanya berimplikasi pada ekstremitas bawah, tetapi juga pembuluh darah secara keseluruhan. Sebagai penyakit aterosklerosis difus, PAD berhubungan dengan aterosklerosis di jantung dan arteri karotis. Peripheral Arterial Disease dapat dinilai dengan menggunakan Ankle Brachial Index (ABI). Ankle Brachial Index adalah ratio tekanan sistolik ankle dan brachial dapat digunakan untuk menilai severitas oklusi arteri perifer yang merupakan gambaran penyumbatan arteri secara umum. Pengaruh cerebrovascular disease terhadap gangguan kognitif telah diketahui, namun hubungan antara PAD dengan gangguan kognitif belum sepenuhnya dipahami. Beberapa peneliti melaporkan bahwa penurunan nilai $A B I<0,9$ pada PAD dihubungkan dengan penurunan fungsi kognitif. ${ }^{2,6-8}$

Penelitan prospektif yang dilakukan di Amerika Serikat terhadap sebuah komunitas yang di follow up selama 7 tahun mendapatkan hubungan antara penurunan nilai $A B I$ dengan gangguan kognitif. Sejumlah penelitian kohort lain, termasuk Edinburg artery study dan Honolulu aging study, mendapatkan $\mathrm{ABI}$ memiliki nilai prediktif terhadap gangguan kognitif di masa yang akan datang dan peningkatan risiko demensia. Studi cross sectional pada populasi Iwaki Health Promotion Project Sugawa di Jepang mendapatkan hasil bahwa $\mathrm{ABI}$ rendah merupakan faktor risiko independent terhadap gangguan kognitif. ${ }^{9,10}$ Penelitian Oleh Tapiheru yang menilai hubungan $\mathrm{ABI}$ dengan skor MMSE dan CDT (Clock Drawing Test) pada pasien dengan PAD didapatkan korelasi positif antara $A B I$ dengan MMSE, namun tidak untuk CDT. ${ }^{10,11}$

Montreal Cognitive Assessment (MoCA) merupakan test yang ideal untuk menilai pasien dengan gangguan kognitif, demensia alzheimer dan demensia vaskuler, karena MoCA dapat digunakan untuk menilai fungsi kognitif secara keseluruhan. Hasil pemeriksaan MoCA juga bisa disesuaikan dengan tingkat pendidikan pasien dan dapat digunakan pada pasien tunanetra. Ada peneliti yang mendapatkan bahwa MoCA memiliki sensitifitas dan spesifisitas yang lebih tinggi dibandingkan MMSE. Mereka mengunakan cut 
off point 26, dimana didapatkan MMSE memiliki sensitifitas $18 \%$ untuk mendeteksi Mild Cognitive Impairment, sementara MoCA memiliki sensitifitas $90 \%$. Untuk mendeteksi Demensia Alzheimer, MMSE memiliki sensitifitas $78 \%$, sedangkan MoCA memiliki sensitifitas $100 \% .^{12}$ Penelitian tentang hubungan $\mathrm{ABI}$ dengan gangguan kognitif di Indonesia masih sedikit dan belum pernah dilakukan di Sumatera Barat. Penelitian ini bertujuan untuk mengetahui hubungan antara nilai Ankle Brachial Index dengan fungsi kognitif pada pasien lanjut usia yang berobat ke poliklinik saraf RS DR M Djamil Padang.

\section{METODE}

Penelitian ini dilakukan pada 75 orang pasien lanjut usia yang berobat ke poliklinik saraf RS DR M Djamil Padang. Pengumpulan sampel mengunakan metode consecutive sampling sesuai dengan kriteria inklusi dan eksklusi penelitian. Kriteria inklusi penelitian ini adalah semua pasien lanjut usia (usia diatas 60 tahun) yang datang berobat ke Poliklinik RS DR M Djamil Padang dan telah memberikan persetujuan untuk berpartisipasi pada penelitian ini dengan menandatangani informed consent. Kriteria eksklusi adalah penderita stroke, demensia, gangguan psikiatri, dan pasien dengan gangguan atau riwayat gangguan sistem saraf pusat (SSP) lainnya seperti infeksi, riwayat cedera kepala. Semua subjek dilakukan pencatatan karakteristik demografi meliputi umur, jenis kelamin dan tingkat pendidikan, serta penyakit vaskuler yang diderita. Pemeriksaan $A B I$ yang dinilai dengan membandingkan tekanan darah sistolik pada ankle dan brachial dengan menggunakan tensimeter Riester dan stetoskop Littman. Nilai $A B I<0,9$ dianggap mengalami PAD. Pemeriksaan fungsi kognitif dengan instrument Indonesia Montreal Cognitif Assesment (InaMoCA). Nilai InaMoCA $<26$ dianggap rendah.

Data disajikan dalam bentuk tabel distribusi frekuensi dan statistik deskriptif analitik. Analisa hubungan antar variabel mengunakan uji $\chi^{2}$ dengan nilai $P<0,05$.

\section{HASIL DAN PEMBAHASAN}

Penelitian dilakukan terhadap 75 orang lanjut usia, dimana sebagian besar pasien adalah wanita (64\%). Usia rata-rata pasien adalah 67 tahun. Pendidikan tertinggi terbanyak adalah SMU (48\%) dan sebagian besar (72\%) sampel memiliki penyakit vaskuler. Pemeriksaan nilai $A B I$ didapatkan nilai yang normal sebanyak 44 orang $(58,7 \%)$, rendah sebanyak 31 orang (41,3\%). Pemeriksaan InaMoCA, ditemukan sebanyak 48 orang $(64 \%)$ terganggu dan 27 orang (36\%) tidak terganggu. Karakteristik dasar penelitian dapat dilihat pada Table 1.

\begin{tabular}{|c|c|}
\hline KARAKTERISTIK & $\begin{array}{l}\text { FREKUENSI (\%) } \\
\mathrm{n}=75\end{array}$ \\
\hline \multicolumn{2}{|l|}{ JENIS KELAMIN } \\
\hline Laki-laki & $30(40)$ \\
\hline Perempuan & $45(60)$ \\
\hline \multicolumn{2}{|l|}{ UMUR } \\
\hline 60-69 tahun & $46(61,3)$ \\
\hline 70-79 tahun & $25(33,3)$ \\
\hline$>80$ & $4(5,3)$ \\
\hline \multicolumn{2}{|c|}{ TINGKAT PENDIDIKAN } \\
\hline \multicolumn{2}{|l|}{ SD } \\
\hline SMP & $12(16)$ \\
\hline SMU & $15(20)$ \\
\hline Pendidikan Tinggi & $\begin{array}{l}36(48) \\
12(16)\end{array}$ \\
\hline \multicolumn{2}{|c|}{ PENYAKIT VASKULER } \\
\hline Tidak ada & $\begin{array}{l}54(72) \\
21(28)\end{array}$ \\
\hline \multicolumn{2}{|l|}{ ABI } \\
\hline Normal & $44(58,7)$ \\
\hline Rendah & $31(41,3)$ \\
\hline \multicolumn{2}{|l|}{ InaMoCA } \\
\hline Terganggu & $48(64)$ \\
\hline Tidak terganggu & $27(36)$ \\
\hline
\end{tabular}


Hubungan nilai Ankle Brachial Index (ABI) dengan fungsi kognitif dengan menggunakan instrumen InaMoCA dan hubungan antara karakteristik lain yang dianggap sebagai confounding factors dengan fungsi kognitif. Hasilnya tidak didapatkan hubungan antara nilai $A B I$ dengan fungsi kognitif $p=0.165$. Tidak didapatkan hubungan antara karakteristik pasien (umur, tingkat pendidikan dan penyakit vaskuler) dengan fungsi kognitif $(p>0,05)$. Hubungan karakteristik pasien dengan fungsi kognitif yang dinilai dengan Montreal Cognitive Assesment (MoCA) ditampilkan pada Tabel 2.

Tabel 2. Hubungan Antara Karakteristik Pasien Dengan Fungsi Kognitif Pada Pasien Lanjut Usia

\begin{tabular}{|c|c|c|c|}
\hline \multirow[t]{2}{*}{ Variabel } & \multicolumn{2}{|c|}{ Kognitif } & \multirow[b]{2}{*}{$\mathbf{P}$} \\
\hline & $\begin{array}{c}\text { Normal } \\
(\%)\end{array}$ & $\begin{array}{c}\text { Tidak } \\
(\%)\end{array}$ & \\
\hline \multicolumn{4}{|l|}{ PENDIDIKAN } \\
\hline SD & 16,7 & 83,3 & \\
\hline SMP & 26,7 & 73,3 & \\
\hline SMU & 44,4 & 55,6 & 0,085 \\
\hline Peguruan Tinggi & 41,7 & 64,0 & \\
\hline \multicolumn{4}{|l|}{ KELOMPOK UMUR } \\
\hline \multicolumn{4}{|l|}{$60-69$} \\
\hline $70-79$ & 45,7 & 54,3 & \\
\hline \multirow[t]{2}{*}{$>80$} & 24,0 & 76,0 & 0,59 \\
\hline & 0 & 100 & \\
\hline \multicolumn{4}{|l|}{ PENYAKIT } \\
\hline \multicolumn{4}{|l|}{ VASKULER } \\
\hline TIDAK ADA & 37,0 & 63,0 & \\
\hline ADA & 33,3 & 66,7 & 0,764 \\
\hline \multicolumn{4}{|l|}{$\mathrm{ABI}$} \\
\hline NORMAL & 48,1 & 51,9 & 0,165 \\
\hline RENDAH & 64,6 & 41,3 & \\
\hline
\end{tabular}

hubungan antara nilai Ankle Brachial Index dan fungsi kognitif pada jenis kelamin wanita dimana $p=0,042$, namun tidak pada jenis kelamin laki-laki. Hubungan antara ABI dengan fungsi kognitif berdasarkan jenis kelamin di poliklinik Saraf RS Dr. M. Djamil Padang ditampilkan pada Tabel 3.
Tabel 3. Hubungan Antara Ankle Brachial Index (ABI) dengan Fungsi Kognitif Berdasarkan jenis kelamin

\begin{tabular}{cccc}
\hline \multirow{2}{*}{ Variabel } & \multicolumn{2}{c}{ Kognitif } & \multirow{2}{*}{$\begin{array}{c}\text { Tidak } \\
(\%)\end{array}$} \\
\cline { 2 - 3 } & Normal (\%) & \\
\hline Pria & 26,7 & 73,7 & 0,659 \\
Normal & 26,7 & 73,7 & \\
$\quad$ Tidak & & & \\
Wanita & 31,0 & 69,0 & 0,042 \\
Normal & 42,2 & 57,8 & \\
Tidak &
\end{tabular}

Beberapa penelitian sebelumnya telah membuktikan bahwa terdapat hubungan antara $\mathrm{ABI}$ dengan fungsi kognitif. Aterosklerosis melibatkan beberapa proses yang terintegrasi, termasuk gangguan lipid, aktivasi platelet, disfungsi endotel, inflamasi, stress oksidatif, aktifasi sel-sel otot polos, perubahan metabolisme, remodeling dan faktor genetik. Penebalan arteri di perifer diperkirakan merupakan gambaran penebalan dari arteri tubuh secara keseluruhan termasuk arteri yang mendarahi otak. Proses ini berhubungan dengan penurunan oksigenasi ke otak. ${ }^{13,14}$

Pemeriksaan $A B I$ sangat sederhana dan dapat memberikan informasi terpercaya mengenai kondisi aterosklerosis yang berhubungan dengan fungsi kognitif. Nilai $A B I$ mempunyai sensitifitas $95 \%$ dan spesifisitas 99 $\%$ dalam menilai peripheral arterial disease dibandingkan modalitas pemeriksaan lain seperti angiografi, sedangkan menurut Guo nilai $A B I$ dalam menentukan PAD memiliki sensitifitas sebesar $91 \%$ dan spesifisitas $86 \% .6,10,15,16$

Penurunan nilai $A B I$ secara signifikan berhubungan dengan peningkatan risiko demensia vaskuler. Mekanisme potensial yang mendasari kejadian ini adalah oklusi arteri serebral progresif, kehilangan sel-sel otak serta jaringan penunjang dan penurunan kognitif dengan berbagai derajat. Terdapat juga bukti yang kuat antara PAD dengan 
inflamasi, yang juga turut berperan pada patogenesis aterosklerosis serta hubungannya dengan onset menderita demensia dan Alzheimer disease. ${ }^{9}$

Penelitian ini tidak didapatkan hubungan antara Ankle Brachial Index dengan fungsi kognitif secara umum. Hal ini sangat berbeda dengan Honolulu aging study mendapatkan hasil bahwa nilai Ankle Brachial Index yang rendah berhubungan demensia vaskuler dan demensia Alzheimer. ${ }^{9}$ Demikian juga dengan Edinburg artery study yang menyimpulkan bahwa penilaian Ankle Brachial Index dapat digunakan untuk megidentifikasi lanjut usia dengan gangguan kognitif. Penelitian dengan desain kohort ini menggunakan nilai $A B I$ sebagai marker aterosklerosis umum dan menghubungkannya dengan gangguan kognitif 10 tahun kemudian, dengan jumlah sampel 707 orang. ${ }^{10}$

Sebuah sistematik review yang menilai hubungan antara nilai $\mathrm{ABI}$ yang rendah dengan beberapa derajat gangguan kognitif seperti: cognitive impairment, demensia dan alzheimer disease (AD) pada populasi umum menyimpulkan bahwa nilai $A B I$ yang rendah dapat dijadikan sebagai penanda (marker) terhadap cognitive impairment bahkan demensia. ${ }^{17}$

Penelitian ini mendapatkan hasil yang sangat berbeda dengan sejumlah penelitian yang menghubungan nilai $A B I$ dengan fungsi kognitif sebelumnya. Setelah dilakukan analisa, kemungkinan karena penelitian ini memiliki jumlah sampel yang sangat sedikit dibandingkan dengan penelitian serupa sebelumnya. Selain itu penelitian ini hanya melakukan pemeriksaan dalam satu waktu, tanpa melalukan peninjauan nilai $\mathrm{ABI}$ dan fungsi kognitif beberapa tahun ke depan.
Metode pemeriksaan $A B I$ juga berbeda dengan sebagian besar penelitian $A B I$ sebelumnya, dimana karena keterbatan prasarana, penelitian ini hanya menggunakan tensimeter dan stetoskop, sementara penelitian sebelumnya menggunakan doppler untuk penilaian $A B I$.

Terdapat hal menarik dari penelitian ini, dimana setelah subjek penelitian dikelompokan berdasarkan jenis kelamin, penelitian ini mendapatkan hubungan bermakna antara nilai $A B I$ dengan jenis kelamin wanita. Sebuah penelitian mendapatkan hasil lansia berjenis kelamin perempuan akan memiliki gangguan berjalan, kelemahan motorik dan gangguan kognitif yang lebih berat dibandingkan laki-laki. Penelitian ini melibatkan 27 lansia perempuan dengan PAD dan 22 kontrol. Pemeriksaan fungsi kognitif menggunakan MMSE, dan dilakukan perbandingan antara activity dailiy living ( $A D L$ ) dengan MMSE, instrumental activity dailiy living (IADL) dengan MMSE, serta IADL dengan beberapa penilaian fungsi fisik. Secara signifikan didapatkan gangguan instrumental activity daily living (IADL) pada lansia perempuan dengan peripheral arterial disease dibandingkan dengan kontrol, namun mekanisme pasti yang mendasari hal ini belum diketahui dengan pasti. ${ }^{18}$

Penelitian ini memiliki beberapa kekurangan dimana jumlah sampel yang terlalu kecil serta tidak diklasifikannnya jenis penyakit vaskuler yang diderita oleh sampel, dan juga tidak diklasifikasikan penyakit vaskuler tersebut terkontol atau tidak. Selain itu penelitian ini tidak mecoba menganalisa domain gangguan kognitif yang dialami oleh lansia, seperti fungsi eksekutif, visuospasial, penamaan, memori, bahasa, dan lain-lain, sementara InaMoCA merupakan instrumen 
pemeriksaan yang menilai domain kognitif cukup lengkap. Namun setidaknya penelitian ini dapat dijadikan referensi untuk penelitian hubungan $A B I$ dengan ganguan kognitif selanjutnya, terutama pada lansia berjenis kelamin perempuan.

\section{SIMPULAN}

Penelitian ini tidak mendapatkan hubungan yang bermakna antara nilai Ankle Brachial Index ( $\mathrm{ABI}$ ) dengan fungsi kognitif yang dinilai dengan menggunakan InaMoCA pada populasi lanjut usia, namun setelah

\section{DAFTAR RUJUKAN}

1. Badan Penelitian dan Pengembangan Kesehatan. Laporan hasil riset kesehatan dasar nasional. Departemen Kesehatan Republik Indonesia. 2007.

2. Mohler, E.R. Peripheral arterial disease identification and implication. Arc Intern Med. 2003; 163:2306-14.

3. Bourdeux ML, Reichh LM, Hirsth AT. The epidemiology and natural history of peripheral arterial disease in: Coffman Jd \& Eberhart RT.ed. peripheral arterial disease: diagnosis and treatment. New Jersey: Humana Press Inc. 2003; 21-34.

4. Hirch et al. practice guidelines for the management of patient with peripheral arterial disease (PAD) circulation. J American Heart Assoc. 2005:468-7.

5. Selvin E., Erlinger TP., Prevalence of and risk for peripheral arterial disease in the United States: Result from the national Health and nutrition survey. American heart association journal. Circulation. 2004; 110:738-43.

6. SIGN. Diagnosis and management of peripheral arterial disease. Scottish Intercollegiate Guidelines Network. Edinburgh 2006.

7. Gatto NM. Cardiovasculer disease risk factor and cognitive function. Desertasi. Faculty of dilakukan pembagian lanjut usia berdasarkan jenis kelamin, didapatkan hubungan antara nilai $A B I$ dengan fungsi kognitif pada jenis kelamin perempuan. Tidak ditemukan hubungan yang bermakna antara faktor-faktor lain (umur, pendidikan, penyakit vaskuler) dengan fungsi kognitif. Masih dibutuhkan penelitian lebih lanjut dengan skala yang lebih besar dengan waktu pengamatan yang lebih lama untuk mengetahui hubungan antara Ankle Brachial Index dengan fungsi kognitif pada wanita.

The graduate School University of Southern California. 2007.

8. Waldstein et al. Peripheral arterial disease and cognitive impairment. Psychosomatic Medicine 65. 2003:757-63.

9. Lauren D. Masaki KH, White LR, Launer LJ, Ankle-to-brachial index and dementia: the Honolulu-Asia aging study. Circulatio J American Heart Assoc 2007.

10.Price JF, McDowell, Whiteman MC, Deary IJ, Steward MC, Fowkes FG. Ankle brachial index as a predictor of cognitive impairment in general population: ten year follow up of the Edinburg Artery Study. J Am Geriatric Soc. 2006; 54(5):763-9.

11.Tapiheru LA. Hubungan nilai Ankle Brachial Index dengan skor mini mental state examination dan clock drawing test pada penderita peripheral arterial disease. Thesis. 2008. Universitas Sumatera Utara.

12.Nasreddine ZS, Philips NA, Bedirian V, Charbonneau S, Whitehead V, Collin I, Cummings JL, Chertkow $\mathrm{H}$, The Montreal Cognitive As seement, moCA; a brief screening tool for mild cognitive impairment. J Am Geriatic Soc. 2005; 53(4):695-9. 
13.Wandell CR, Zonderman AB, Metter EJ, et al. Carotid intimal medial thickness predict cognitive decline among adult without clinical vasculer disease. J Am Heart Assoc 2009; 40:3180-5.

14.American Heart Association Artherosclerotic Vasculer Disease Conference: Writing Group III. Circulation. 2004; 109:2617-25.

15.Guo X, Li J, Pang W, Zhao M, Luo Y. Sensitivity and specificity of Ankle Brachial Index for detecting angiographic stenosis of peripheral arteries. Circ J. 2008; 72:605-10.

16. Mangiafico RA, Samataro F, Mangiafico $M$. Impaired cognitig peformance in asymptomatic peripheral arterial disease: relation to Creactive protein and D-dimer level. Age and ageing. 35; 60-65.

17. Maelenn G, Victor A, Philippe N, Philippe L, Jean PC, Pierre MP. Ankle-brachial index as a marker of cognitif impairment and dementia in general population. A systematic review. Science direct. 2011; 216(2):251-7.

18.Cucato GG et al. Influence of peripheral arterial disease on daily living avtivities in elderly women. J Vascular nursing. 2016; 34(2):39-43. 